The $5^{\text {th }}$ Conf. of SSFOP “Maximizing utilization of ornamental plants in urban areas

landscaping”, Cairo, Egypt, 24/2/2019

Scientific J. Flowers \& Ornamental Plants

www.ssfop.com/journal

ISSN: 2356-7864

doi: 10.21608/sjfop.2019.28331

\title{
EFFECT OF PLANTING CONDITIONS AND PLANTING DATES ON VEGETATIVE GROWTH, FLOWERING, BULBS PRODUCTION AND CHEMICAL CONSTITUENTS OF IRIS TINGITANA CV. WEDGEWOOD PLANTS
}

\author{
Z.H.R Abdel-Said \\ Ornamental Plants and Landscape Gardening Res. Dept., Hort. Res. Inst., ARC, Giza, Egypt.
}

\begin{abstract}
The present experiment was consummated throughout two successive seasons (2016/2017 and 2017/2018) at the nursery of Horticulture Research Institute, Agricultural Research Center, Giza, Egypt with the aim to solve one of the most important problem facing most of winter cultivated crops under local condition in Egypt. It was intended to overcome the problem of high atmospheric temperature which prevailed during the early months of autumn and consequently led to deteriorate plant quality of many crops. Thus, the effects of shading and open field conditions (saran house of $65 \%$ shading and full sun light of open field conditions), besides the effects of planting dates and their interaction were investigated on growth, flowering, bulbs, bulblets yield and quality and chemical constituents of Iris tingitana cv. Wedgewood plants.
\end{abstract}

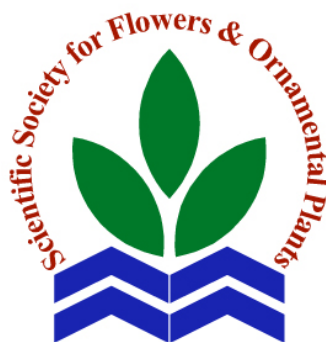

Scientific J. Flowers \& Ornamental Plants, 6(1):1-19 (2019).

Received: 26/12/2018

Accepted: $13 / 1 / 2019$

Main results of the study could be summarized in the following: growing the bulbs preliminary under shading followed by open field conditions was the best for improving most of plant traits studied in the two seasons as produced the highest values of number of leaves/plant, induced early flowering, gave the highest values of spike stem length, increased fresh weight of cut spike and the newly formed bulbs. Moreover, raised fresh weight of bulblets and bulblets yield. With respect to the effect of planting dates, planting the bulbs on October $15^{\text {th }}$, gave beneficial effects in most cases as it was the best planting date in raising vegetative growth height. Moreover, it gave the utmost high values with significant effect on number of leaves/plant. Also, planting the bulbs on October $15^{\text {th }}$ caused a clear decrement in the time required for flowering, succeeded to raise spike stem length, produced the highest bulblets yield and the highest bulb circumference. Meantime, planting the bulbs at the earliest date of September $15^{\text {th }}$ was the best for elevating fresh weight of cut spike and produced the heaviest fresh weight of bulbs, and recorded the utmost high values of bulblets yield. Referring the effect on chemical constituents the results showed that bulbs planted under open field condition followed by shading was the best in raising pigments content in leaves (chlorophyll a, b and carotenoids) in the two seasons. Meanwhile, the different planting conditions gave means closely near together for the effect of the different planting conditions on total carbohydrates content in the newly formed bulbs, Moreover, clear increment on nitrogen \% in the new bulbs was observed due to growing bulbs grown under open field condition throughout the growing season. Whereas, bulbs grown under 


\section{Z.H.R Abdel-Said}

open field, followed by shading condition, as well as those which grown under shading condition throughout the growing season gave the highest records of phosphorus \% in the new bulbs in both seasons. Results revealed also the prevalence of growing bulbs under either open field condition throughout the growing season in both seasons or those grown under shading followed by open field condition in the first season in raising potassium \% accumulation in new bulbs. Also, clear influences on chemical constituents of the plants were observed due to using the different planting dates. The utmost high values of pigments content in leaves was noticed as a result of planting the bulbs on September $15^{\text {th }}$. Moreover, the highest records of total carbohydrates in new bulbs were gained as a result of planting the bulbs in the same date (September $15^{\text {th }}$ ) in both seasons. Negligible differences on nitrogen \% in bulbs were observed due to the effect of the different planting dates used in both seasons. Whereas, planting the bulbs on October $1^{\text {st }}$ was the best in elevating phosphorus \% in bulbs in the two seasons. Meantime, planting the bulbs in the earliest date of September $15^{\text {th }}$ was the best for producing the highest potassium \% in bulbs in the two seasons.

From the aforementioned results and interaction it could be recommended to plant the bulbs under shading condition, followed by open field condition with planting the bulbs on October $15^{\text {th }}$ for improving plant quality of Iris tingitana cv. Wedgewood.

Key words: Iris tingitana cv. Wedgewood, shading, open field, planting dates.

\section{INTRODUCTION}

Iris is a flowering popular plant and comprises 3000 species with countless varieties native to South America and belongs to family Iridaceae (Bailey, 1963). Their showy flowers are remarkable alike for their structure and blending of showy colours which recommended them strongly to horticulturists since early times. Iris tingitana cv. Wedgewood flowers are very popular for local use, for its general beauty. Moreover, it is also demanded for exportation.

Light intensity revealed considerable variations in plant parameters as mentioned by many authors, Nada (1992) on Polianthes tuberosa concluded that, planting the bulbs under shading condition (saran house of $65 \%$ shading) reduced bulbs and bulblets yield. On Easter lily, Sorrentino et al. (1997) found that, flower quality was slightly higher in sunlight plants, whereas dry matter accumulation did not differ between shaded and sunlight plants during the growing season, leaves exposed to full sunlight showed slight reduction influence parameters. Al-Ashry et al. (1998) on Hippeastrum vittatum recorded that, plastic house (20\% shading) shortened the time required for bulb sprouting, increased plant height and spike stem length. Whereas, saran house (65\% shading) increased spike stem length and diameter, flower diameter and fresh weight of cut spike. Meanwhile, open field condition increased total carbohydrate content in leaves, but decreased potassium accumulation. However, saran and plastic houses increased nitrogen and potassium in leaves. Meanwhile, phosphorus accumulation was increased due to planting under saran house condition El-Fawakhry (2001) on Polianthes tuberosa found that $65 \%$ shading increased vegetative growth height, induced earlier flowering, decreased spike yield, but produced the tallest, heaviest 
and thinnest spike. He added that 65\% shading caused a considerable decrement in bulbs and bulblets yield and bulblets fresh weight, but it increased bulb fresh weight and bulb size when compared with full sunlight condition. Badawy et al. (2002) on Iris cv. Purple Sensation concluded that planting the bulbs under shading condition enhanced sprouting and flowering date, increased vegetative growth height at flowering phase and spike stem length, but decreased spike stem diameter, fresh weight of cut spike and bulbs yield. However, bulbs fresh weight and bulblets yield and fresh weight were not significantly affected by light intensity. El-Hanafy et al. (2005) on Freesia refracta cv. Aurora mentioned that growing the plants under shading conditions increased vegetative growth height, number of leaves/plant, spike stem length, number of cormlets/plot (cormlets yield), cormel fresh weight and accumulation rate of nitrogen and, potassium and total carbohydrate in the new corms, but decreased number of corms/plot (corms yield) fresh weight of corm and corm circumference and delayed to some extant flowering date.

El-Naggar et al. (2009) on Hippeastrum vittatum concluded that planting the plant under plastic house condition with average light intensity of 450-500 lux significantly reduced vegetative growth and flowering. On the other hand, planting the plant under full sunlight condition (open field) improved vegetative growth, flowering, bulbs production and chemical composition parameters (number of leaves/plant at flowering time, flower stalk length, flower stalk diameter, bulbs diameter, bulbs fresh and dry weight, number of new bulblets, total chlorophyll content and total carbohydrates content).

Planting dates showed considerable influence on plant traits of many ornamental bulbs, as was mentioned by many authors. Badawy (1998) on Polianthes tuberosa stated that the early planting date (May $2^{\text {nd }}$ ) was the best for producing high flowers yield and quality. Whereas, delaying planting time till July $1^{\text {st }}$ shortened the time required for bulbs flowering, but deteriorated all flowers characters. Similar observations were detected by planting the same plant in succession by Arafa et al. (2000).

Eliwa et al. (2010a) on Freesia refracta $\mathrm{cv}$. Aurora concluded that planting the corms in the earliest date (September $16^{\text {th }}$ ) had great influence on most plant traits. It increased vegetative growth height, number of leaves/plant, spike stem length, spike stem diameter and fresh weight of cut spike. Meanwhile, it increased the time required for corm sprouting and flowering Moreover, the same authors (2010b) added that planting the corms in the earliest date (September $15^{\text {th }}$ ) increased corms yield fresh weight of cormel and total carbohydrate in the produced corms. Whereas, delaying planting date to October $1^{\text {st }}$ i.e. prolonging storage duration at either room or cold storage increased to some extent $\mathrm{N}$ and $\mathrm{K} \%$ in the produce corms.

Therefore, the present experiment was consummated for achieving the hope of producing Iris tingitana cV. Wedgewood plant with best quality by overcoming the undesirable effect of the high atmosphere temperature which prevailed during the beginning of autumn months by means of using shading treatments with different planting dates throughout the high temperature of such duration.

\section{MATERIALS AND METHODS}

The experimental trial was performed throughout two successive seasons (2016/2017 and 2017/2018) at the nursery of Horticulture Research Institute, Agricultural Research Center, Giza, Egypt, with the aim to overcome the undesirable effect on plant quality of Iris tingitana cv. Wedgewood due to the high temperature which prevailed at the beginning of autumn months in Egypt. Thus, the effects of shading and full sunlight exposure (saran house of $65 \%$ shading and full sunlight of open field condition) on growth, flowering, bulbs and bulblets yield 


\section{Z.H.R Abdel-Said}

and quality and some chemical constituents of the plant were investigated.

\section{Plant materials:}

Bulbs of 8-9 cm circumference were used in the two successive seasons.

\section{Planting condition:}

Two types of planting conditions, saran house allowing $65 \%$ shading of light intensity (2500- 3000 f.c. at noon) and open field condition of full sunlight. The temperature which prevailed under open field conditions during the growth cycle of the plant in the two seasons is exhibited in Table (a). Meanwhile, saran house caused a decrement in temperature $\left({ }^{\circ} \mathrm{C}\right)$ comparing with that of the open field conditions at the range of $4-5^{\circ} \mathrm{C}$.

\section{Growing medium:}

Growing medium of the mixture of sand + clay $(1: 1, \mathrm{v} / \mathrm{v})$ was prepared for planting in both seasons. The chemical properties of the growing medium are presented in Table (b).

\section{Procedure:}

The bulbs were lifted from the soil on May $15^{\text {th }}$, in both seasons. After examining and cleaning, bulbs of 8-9 cm circumference were selected and kept at room temperature of $26 \pm 3{ }^{\circ} \mathrm{C}$ during May, $27 \pm 3{ }^{\circ} \mathrm{C}$ during June, $28 \pm 3{ }^{\circ} \mathrm{C}$ during July and August, $27 \pm 3$ ${ }^{\circ} \mathrm{C}$ during September.

The selected bulbs were divided into four lots. They were planted in batches at 15 days intervals from September $15^{\text {th }}$ till November $1^{\text {st }}$, i.e. having 4 planting dates (September $15^{\text {th }}$, October $1^{\text {st }}$, October $15^{\text {th }}$, November $1^{\text {st }}$ ). The bulbs of every batch were re-divided into another four groups for studying the effect of shading and open field condition on plant parameters. In this connection, the bulbs of every batch were classified as follows:

Table a. Maximum, minimum and average monthly temperatures $\left({ }^{\circ} \mathrm{C}\right)$ during the growth cycle of the plant in the two seasons (2016/2017 and 2017/2018).

\begin{tabular}{lcccccc}
\hline & \multicolumn{3}{c}{ 2016/2017 } & \multicolumn{3}{c}{ 2017/2018 } \\
\cline { 2 - 7 } Months & Maximum & Minimum & Average & Maximum & Minimum & Average \\
\hline September & 35.4 & 22.3 & 31.0 & 34.9 & 22.3 & 30.5 \\
October & 32.4 & 19.8 & 27.9 & 31.0 & 18.5 & 26.4 \\
November & 27.4 & 15.5 & 22.7 & 25.5 & 13.7 & 21.4 \\
December & 20.9 & 8.7 & 16.5 & 23.9 & 12.4 & 19.3 \\
January & 19.4 & 10.3 & 15.4 & 19.9 & 11.2 & 16.3 \\
February & 21.5 & 8.0 & 16.9 & 24.7 & 12.5 & 19.8 \\
March & 25.4 & 12.0 & 20.9 & 28.8 & 14.4 & 23.5 \\
April & 28.8 & 15.8 & 24.7 & 29.9 & 15.9 & 25.0 \\
May & 34.6 & 19.4 & 29.3 & 35.1 & 21.1 & 30.0 \\
\hline
\end{tabular}

Table b. Chemical properties of the growing medium used in plantation according to Reclamation and Development Center for Desert Soil, Faculty of Agriculture, Cairo University according to Page (1982).

\begin{tabular}{cccccccccc}
\hline \multirow{2}{*}{$\begin{array}{c}\text { Growth } \\
\text { medium }\end{array}$} & $\mathbf{p H}$ & $\begin{array}{c}\mathbf{E C} \\
\mathbf{d s} / \mathbf{m}^{-\mathbf{1}}\end{array}$ & $\mathbf{N a}^{+}$ & $\mathbf{K}^{+}$ & $\mathbf{C a}^{++}$ & $\mathbf{M g}^{++}$ & $\mathbf{H C O}_{3}^{-}$ & $\mathbf{C l}$ & $\mathbf{S O}_{4}^{--}$ \\
\hline Sand + clay & 7.25 & 5.17 & 29.20 & 0.21 & 18.4 & 14.6 & 2.8 & 4.85 & 1.16 \\
\hline
\end{tabular}


a. Bulbs planted and grown at open field condition all over the growing season of the plant (terminate of the experiment).

b. Bulbs planted and grown under shading condition all over the growing season of the plant (terminate of the experiment).

c. Bulbs which were planted at open field condition at first were transferred to grow under shading condition commencing from the end of November till the terminate of the experiment.

d. Bulbs which were planted under shading condition at first were transferred to grow under open field condition commencing from the end of November till the terminate of the experiment.

Thus, the effect of four planting dates with four planting conditions and their interaction were examined on plant parameters and some chemical constituents of the plants in the two seasons.

The bulbs were planted in $25 \mathrm{~cm}$ diameter plastic pots filled with a mixture of sand/clay (1:1, v/v), (one bulb per pot).

A factorial experiment type in randomized complete block design (RCBD) with three replicates was employed in both seasons. Every treatment contained 15 bulbs, and replicated three times (5 bulbs per replicate).

Regular agricultural practices such as watering, weeding, fertilization ... etc. were carried out whenever needed, where the plants were received Kristalon (19:19:19) at $2 \mathrm{~g} /$ plant throughout the growing season at 15 days interval, till the terminate of the experiment in both seasons.

The following data were recorded: Number of days from planting to sprouting, vegetative growth height at flowering stage (cm), number of leaves/plant at flowering stage, number of days from planting to flowering, spike stem length $(\mathrm{cm})$, spike stem diameter $(\mathrm{cm})$ and fresh weight of cut spike (g), number of the new bulbs/plot (bulbs yield), bulb circumference $(\mathrm{cm})$ and fresh weight of bulb (g), No. of bulblets/polt (bulblets yield) and bulblet fresh weight (g).

\section{Chemical analysis of leaves:}

Determination of chlorophylls (a and b) and total carotenoids in fresh leaves were carried out according to Wettstein (1957). Total carbohydrates content of leaves was determined by using colorimetric methods described by Dubois et al. (1956). Nitrogen content was determined by micro-Kjeldahle (Blake, 1965), phosphorus content was colorimetrically determined in the acid digested using ascorbic acid methods (John, 1970). Potassium was determined by using the flamephotometer (Dewis and Freitas, 1970).

Data were then tabulated and statistically analyzed using SAS program (1994) and means were compared by L.S.D. method according to Snedecor and Cochran (1968).

\section{RESULTS AND DISCUSSION}

\section{Effect on vegetative growth parameters:}

Evidently, data registered in Table (1) indicate that the earliest sprouting bulbs in both seasons, was a result of growing bulbs preliminary under open field condition followed by shading condition. Such treatment significantly declined the time required from planting to sprouting to only 29.22 and 30.58 days in the first and second seasons, respectively. Meanwhile, the longest duration from planting to sprouting was obtained as a result of growing the bulbs under shading followed by open field condition, scoring 35.33 and 36.18 days in the first and second season, respectively. The different planting dates, on the other side, cleared that delaying planting date to November $1^{\text {st }}$, much decreased the time required from planting to sprouting, comparing with that gained from the other planting dates were used in the two seasons, to the extent that the scored values were declined to only 16.77 and 18.08 days in the first and second seasons, respectively. In the same line, the earliest planting date (September $15^{\text {th }}$ ) considerably increased such 
Table 1. Effect of planting conditions and planting dates on number of days from planting to sprouting of Iris tingitana cv. Wedgewood during 2016/2017 and 2017/2018 seasons.

\begin{tabular}{|c|c|c|c|c|c|c|c|c|c|c|}
\hline \multirow{2}{*}{ Dates (B) } & $\begin{array}{l}\text { Open/ } \\
\text { Open }\end{array}$ & $\begin{array}{c}\text { Shade/ } \\
\text { Open }\end{array}$ & $\begin{array}{l}\text { Open/ } \\
\text { Shade }\end{array}$ & $\begin{array}{l}\text { Shade/ } \\
\text { Shade }\end{array}$ & Means & $\begin{array}{l}\text { Open/ } \\
\text { Open }\end{array}$ & $\begin{array}{c}\text { Shade/ } \\
\text { Open }\end{array}$ & $\begin{array}{l}\text { Open/ } \\
\text { Shade }\end{array}$ & $\begin{array}{l}\text { Shade/ } \\
\text { Shade }\end{array}$ & Means \\
\hline & \multicolumn{5}{|c|}{$1^{\text {st }}$ season } & \multicolumn{5}{|c|}{$2^{\text {nd }}$ season } \\
\hline Sep. 15 & 53.80 & 55.13 & 45.33 & 50.77 & 51.26 & 54.67 & 54.70 & 46.63 & 51.47 & 51.87 \\
\hline Oct. 1 & 39.73 & 42.00 & 29.53 & 32.13 & 35.85 & 40.63 & 43.23 & 31.30 & 33.36 & 37.13 \\
\hline Oct. 15 & 24.40 & 26.87 & 24.87 & 26.57 & 25.68 & 25.73 & 28.33 & 26.13 & 27.87 & 27.02 \\
\hline Nov. 1 & 14.30 & 17.33 & 14.13 & 18.30 & 16.77 & 16.30 & 18.43 & 18.23 & 19.37 & 18.08 \\
\hline Means & 33.06 & 35.33 & 29.22 & 31.94 & & 34.33 & 36.18 & 30.58 & 33.02 & \\
\hline LSD at 0.05 & $\begin{array}{l}A=2.924 \\
B=2.924 \\
A \times B=5.8\end{array}$ & & & & & $\begin{array}{l}A=2.578 \\
B=2.578 \\
A \times B=5 .\end{array}$ & & & & \\
\hline
\end{tabular}

duration in both seasons, scoring 51.26 and 51.87 days in the first and second seasons, respectively. However, the increment in the time required from planting to sprouting due to the early planting date is in agreement with the finding of Eliwa et al. (2010a) on Freesia refracta cv. Aurora. The interactions revealed that the earliest sprouting bulbs obtained as a result of bulbs planted on November $1^{\text {st }}$ and grown at open field, followed by shading conditions in the first season and those which planted on November $1^{\text {st }}$ under open field condition throughout the growth season in the second one, registering 14.13 and 16.30 days in the first and second seasons, respectively. Meanwhile, the opposite was the right for bulbs planted on September $15^{\text {th }}$ under shading followed by open field condition in both seasons, registering 55.13 and 54.70 days in the first and second seasons, respectively.

Vegetative growth height, on the other hand (Table 2) was also affected by the different treatments were used in the two seasons, where the highest value was recorded due to bulbs were grown at either open field followed by shading condition or those which grown all over the season under shading condition. These treatments considerably increased vegetative growth height to the maximum values (91.38 and $92.13 \mathrm{~cm}$ in the first season, and 93.03 and
$94.05 \mathrm{~cm}$ in the second one, respectively). Meanwhile, the least scores were obtained due to growing plants under either open field condition throughout the growing season or from bulbs which grown under shading followed by open field condition in both seasons. These treatments scored 63.78 and $65.82 \mathrm{~cm}$ in the first season and 65.28 and $67.30 \mathrm{~cm}$ in the second one, respectively. The different planting dates on the other hand, revealed that planting the bulbs on October $15^{\text {th }}$ was the best planting dates in raising vegetative growth height in the two seasons (83.17 and $84.78 \mathrm{~cm}$, respectively). In contrast, delaying planting date to November $1^{\text {st }}$ gave the least scores in both seasons, scoring only 71.33 and $73.07 \mathrm{~cm}$ in the first and second seasons, respectively. In the matter of the interaction, the highest records were obtained due to planting the bulbs on September $15^{\text {th }}$, with growing plants under shading condition all over the growth season in the two seasons scoring 98.50 and $100.37 \mathrm{~cm}$ in the first and second seasons, respectively. In contrast, the lowest records were obtained as a result of planting the bulbs on November $1^{\text {st }}$ with growing plants under open field condition all over the growing season, registering only 57.67 and $59.10 \mathrm{~cm}$ in the first and second seasons, respectively.

The significantly highest values of number of leaves/plant were gained resulting 
Table 2. Effect of planting conditions and planting dates on vegetative growth height (cm) of Iris tingitana cv. Wedgewood during 2016/2017 and 2017/2018 seasons.

\begin{tabular}{|c|c|c|c|c|c|c|c|c|c|c|}
\hline \multirow{2}{*}{ Dates (B) } & $\begin{array}{c}\text { Open/ } \\
\text { Open }\end{array}$ & $\begin{array}{c}\text { Shade/ } \\
\text { Open }\end{array}$ & $\begin{array}{l}\text { Open/ } \\
\text { Shade }\end{array}$ & $\begin{array}{l}\text { Shade/ } \\
\text { Shade }\end{array}$ & Means & $\begin{array}{l}\text { Open/ } \\
\text { Open }\end{array}$ & $\begin{array}{c}\text { Shade/ } \\
\text { Open }\end{array}$ & $\begin{array}{l}\text { Open/ } \\
\text { Shade }\end{array}$ & $\begin{array}{l}\text { Shade/ } \\
\text { Shade }\end{array}$ & Means \\
\hline & \multicolumn{5}{|c|}{$1^{\text {st }}$ season } & \multicolumn{5}{|c|}{$2^{\text {nd }}$ season } \\
\hline Sep. 15 & 67.63 & 66.30 & 89.07 & 98.50 & 80.38 & 68.97 & 67.67 & 90.97 & 100.37 & 81.99 \\
\hline Oct. 1 & 64.03 & 67.63 & 92.37 & 88.90 & 78.23 & 65.60 & 68.90 & 93.93 & 90.90 & 79.83 \\
\hline Oct. 15 & 65.80 & 69.17 & 101.53 & 96.17 & 83.17 & 67.47 & 70.67 & 102.80 & 98.17 & 84.78 \\
\hline Nov. 1 & 57.67 & 60.17 & 82.53 & 84.93 & 71.33 & 59.10 & 61.97 & 84.43 & 86.77 & 73.07 \\
\hline Means & 63.78 & 65.82 & 91.38 & 92.13 & & 65.28 & 67.30 & 93.03 & 94.05 & \\
\hline LSD at 0.05 & $\begin{array}{l}A=5.141 \\
B=5.141 \\
A \times B=9.8\end{array}$ & & & & & $\begin{array}{l}\mathrm{A}=4.24 \\
\mathrm{~B}=4.243 \\
\mathrm{~A} \times \mathrm{B}=8\end{array}$ & & & & \\
\hline
\end{tabular}

from growing plants under shading followed by open field condition in both seasons (Table 3). Such treatment scored 6.06 and 6.25 in the first and second seasons, respectively. Whereas, the least scores were a result of growing plants under shading condition throughout the growth season, registering only 4.44 and 4.77 in the first and second season, respectively. The different planting dates, on the other side revealed that the utmost high values with significant effect on number of leaves/plant was obtained due to planting on October $15^{\text {th }}$, scoring 5.70 and 5.91 in the first and second seasons, respectively. Meanwhile, the opposite was the right for bulbs planted in the latest date of November $1^{\text {st }}$, where the least scores were obtained in this regard (4.46 and 4.76 in the first and second seasons, respectively). Concerning the interaction, it is evident from the tabulated data the prevalence of planting on October $15^{\text {th }}$, under shading followed by open field conditions in raising number of leaves/plant in both seasons (6.80 and 7.00, respectively). In contrast the least scores of the same trait was obtained due to planting the bulbs in the latest date (November $1^{\text {st }}$ ) with planting the bulbs under shading condition throughout the growing season of the plant, registering only 4.00 and 4.40 in the first and second seasons, respectively.

The previous results indicated the superiority of using shading condition in increasing vegetative growth height.
However, such increment might be due to the increase of endogenous gibberellins as a result of shading condition under saran house which increased the rate of cell division and elongation and finally the vegetative growth height at flowering stage. These results are in parallel with those of Nada (1992) and ElFawakhry (2001) on Polianthes tuberosa. Moreover, Badawy et al. (2002) on Iris tingitana cv. Purple Sensation concluded that planting the bulbs under shading condition increased vegetative growth height at flowering phase. Also, El-Hanafy et al. (2005) on Freesia refracta cv. Aurora concluded that growing the plants under shading conditions increased vegetative growth height.

\section{Effect on flowering traits:}

Using shading condition at the early growth stages followed by open field condition proved its mastery in inducing the earliest flowering comparing with that obtained from growing under open field condition all over the growing season of the plant (Table 4). Such treatment considerably decreased the time required for flowering to the extent that they induced flowering after only 125.87 and 127.17 days against of 152.15 and 153.58 of bulbs planted under open field condition, throughout the growing season in the first and second seasons, respectively. The beneficial effect of shading treatment in inducing early flowering was in 


\section{Z.H.R Abdel-Said}

Table 3. Effect of planting conditions and planting dates on number of leaves/plant of Iris tingitana cv. Wedgewood during $2016 / 2017$ and $2017 / 2018$ seasons.

\begin{tabular}{|c|c|c|c|c|c|c|c|c|c|c|}
\hline \multirow{2}{*}{ Dates (B) } & $\begin{array}{c}\text { Open/ } \\
\text { Open }\end{array}$ & $\begin{array}{c}\text { Shade/ } \\
\text { Open }\end{array}$ & $\begin{array}{l}\text { Open/ } \\
\text { Shade }\end{array}$ & $\begin{array}{l}\text { Shade/ } \\
\text { Shade }\end{array}$ & Means & $\begin{array}{l}\text { Open/ } \\
\text { Open }\end{array}$ & $\begin{array}{c}\text { Shade/ } \\
\text { Open }\end{array}$ & $\begin{array}{l}\text { Open/ } \\
\text { Shade }\end{array}$ & $\begin{array}{l}\text { Shade/ } \\
\text { Shade }\end{array}$ & Means \\
\hline & \multicolumn{5}{|c|}{$1^{\text {st }}$ season } & \multicolumn{5}{|c|}{$2^{\text {nd }}$ season } \\
\hline Sep. 15 & 6.70 & 6.17 & 4.33 & 4.17 & 5.34 & 6.93 & 6.40 & 4.60 & 4.43 & 5.59 \\
\hline Oct. 1 & 5.30 & 6.33 & 4.73 & 4.87 & 5.31 & 5.50 & 6.50 & 4.87 & 5.10 & 5.49 \\
\hline Oct. 15 & 6.07 & 6.80 & 5.20 & 4.73 & 5.70 & 6.27 & 7.00 & 5.43 & 4.97 & 5.91 \\
\hline Nov. 1 & 4.60 & 4.93 & 4.30 & 4.00 & 4.46 & 4.90 & 5.10 & 4.63 & 4.40 & 4.76 \\
\hline Means & 5.67 & 6.06 & 4.64 & 4.44 & & 5.90 & 6.25 & 4.88 & 4.77 & \\
\hline LSD at 0.05 & $\begin{array}{l}A=0.396 \\
B=0.396 \\
A \times B=0.7\end{array}$ & & & & & $\begin{array}{l}\mathrm{A}=0.405 \\
\mathrm{~B}=0.405 \\
\mathrm{~A} \times \mathrm{B}=0.8\end{array}$ & & & & \\
\hline
\end{tabular}

Table 4. Effect of planting conditions and planting dates on number of days from planting to flowering of Iris tingitana cv. Wedgewood during 2016/2017 and 2017/2018 seasons.

\begin{tabular}{|c|c|c|c|c|c|c|c|c|c|c|}
\hline \multirow{2}{*}{$\begin{array}{r}\text { Conditions } \\
\text { (A) }\end{array}$} & $\begin{array}{l}\text { Open/ } \\
\text { Open }\end{array}$ & $\begin{array}{c}\text { Shade/ } \\
\text { Open }\end{array}$ & $\begin{array}{l}\text { Open/ } \\
\text { Shade }\end{array}$ & $\begin{array}{l}\text { Shade/ } \\
\text { Shade }\end{array}$ & Means & $\begin{array}{l}\text { Open/ } \\
\text { Open }\end{array}$ & $\begin{array}{c}\text { Shade/ } \\
\text { Open }\end{array}$ & $\begin{array}{l}\text { Open/ } \\
\text { Shade }\end{array}$ & $\begin{array}{l}\text { Shade/ } \\
\text { Shade }\end{array}$ & Means \\
\hline & \multicolumn{5}{|c|}{$1^{\text {st }}$ season } & \multicolumn{5}{|c|}{$2^{\text {nd }}$ season } \\
\hline $\begin{array}{l}\text { Sep. } 15 \\
\end{array}$ & 158.67 & 130.67 & - & - & 144.67 & 160.33 & 133.67 & - & - & 147.00 \\
\hline Oct. 1 & 162.07 & 130.47 & - & - & 146.27 & 163.00 & 131.67 & - & - & 147.33 \\
\hline Oct. 15 & 143.00 & 120.33 & - & - & 131.67 & 145.00 & 121.00 & - & - & 133.00 \\
\hline Nov. 1 & 144.87 & 122.00 & - & - & 133.43 & 146.00 & 122.33 & - & - & 134.17 \\
\hline Means & 152.15 & 125.87 & - & - & & 153.58 & 127.17 & - & - & \\
\hline LSD at 0.05 & $\begin{array}{l}A=2.150 \\
B=4.105 \\
A \times B=4 . ?\end{array}$ & & & & & $\begin{array}{l}\mathrm{A}=2.215 \\
\mathrm{~B}=4.229 \\
\mathrm{~A} \times \mathrm{B}=5 .\end{array}$ & & & & \\
\hline
\end{tabular}

harmony agreement with the finding of ElFawakhry (2001) on Polianthes tuberosa, who found that $65 \%$ shading induced earlier flowering. On the other hand delaying planting date to October $15^{\text {th }}$ and November $1^{\text {st }}$ caused a clear decrement in the time required for flowering in both seasons, comparing with that recorded from the earliest planting dates of September $15^{\text {th }}$ and October $1^{\text {st }}$ in the two seasons (131.67, 133.43 days and 133.00 and 134.17 days against 144.67, 146.27 and 147.00, 147.33 in the first and second seasons, respectively). In the matter of the interaction, data listed in Table (4) revealed that the shortest time required for flowering was recorded by planting the bulbs on October $15^{\text {th }}$ under shading followed by open field conditions in both seasons (120.33 and 121.00 days in the first and second seasons, respectively). Whereas, the longest period was a result of growing bulbs which planted on October $1^{\text {st }}$ under open field condition throughout the growing season, registering 162.07 and 163.00 days in the first and second seasons, respectively.

The significantly highest values of spike stem length were recorded resulting from planting under shading, followed by open field conditions in both seasons (Table 5). Such treatment raised the scored values to 33.48 and $35.57 \mathrm{~cm}$ against 31.04 and 32.97 $\mathrm{cm}$ of plants grown at open field condition throughout the growing season of the plant in the first and second seasons, respectively. In the connection, the beneficial effect of shading condition in raising spike stem 
Table 5. Effect of planting conditions and planting dates on spike stem length $(\mathrm{cm})$ of Iris tingitana cv. Wedgewood during 2016/2017 and 2017/2018 seasons.

\begin{tabular}{|c|c|c|c|c|c|c|c|c|c|c|}
\hline \multirow{2}{*}{ Dates (B) } & $\begin{array}{c}\text { Open/ } \\
\text { Open }\end{array}$ & $\begin{array}{c}\text { Shade/ } \\
\text { Open }\end{array}$ & $\begin{array}{l}\text { Open/ } \\
\text { Shade }\end{array}$ & $\begin{array}{l}\text { Shade/ } \\
\text { Shade }\end{array}$ & Means & $\begin{array}{l}\text { Open/ } \\
\text { Open }\end{array}$ & $\begin{array}{c}\text { Shade/ } \\
\text { Open }\end{array}$ & $\begin{array}{l}\text { Open/ } \\
\text { Shade }\end{array}$ & $\begin{array}{l}\text { Shade/ } \\
\text { Shade }\end{array}$ & Means \\
\hline & \multicolumn{5}{|c|}{$1^{\text {st }}$ season } & \multicolumn{5}{|c|}{$2^{\text {nd }}$ season } \\
\hline Sep. 15 & 30.00 & 34.70 & - & - & 32.35 & 31.67 & 36.83 & - & - & 34.25 \\
\hline Oct. 1 & 29.33 & 35.40 & - & - & 32.37 & 31.33 & 37.37 & - & - & 34.35 \\
\hline Oct. 15 & 35.83 & 32.83 & - & - & 34.33 & 37.90 & 35.40 & - & - & 36.65 \\
\hline Nov. 1 & 29.00 & 31.00 & - & - & 30.00 & 31.00 & 32.67 & - & - & 31.83 \\
\hline Means & 31.04 & 33.48 & - & - & & 32.97 & 35.57 & - & - & \\
\hline LSD at 0.05 & $\begin{array}{l}A=2.104 \\
B=4.016 \\
A \times B=5.6\end{array}$ & & & & & $\begin{array}{l}\mathrm{A}=1.930 \\
\mathrm{~B}=3.684 \\
\mathrm{~A} \times \mathrm{B}=4 .\end{array}$ & & & & \\
\hline
\end{tabular}

length was also recorded by a lot of scientists on various ornamental bulbs. El-Fawakhry (2001) on Polianthes tuberosa, found that $65 \%$ shading produced the tallest spike. Badawy et al. (2002) on Iris tingitana cv. Purple Sensation concluded that planting the bulbs under shading condition increased spike stem length. Moreover, El-Hanafy et al. (2005) on Freesia refracta cv. Aurora mentioned that growing the plants under shading condition increased spike stem length. On the other side, planting the bulbs on October $15^{\text {th }}$ succeeded to raise spike stem length to 34.33 and $36.65 \mathrm{~cm}$ giving the utmost high values in the first and second seasons, respectively. With respect to the interaction, data registered in Table (5) showed the prevalence of planting the bulbs on September $15^{\text {th }}$ and October $1^{\text {st }}$ under shading followed by open field condition as well as of bulbs planted on October $15^{\text {th }}$ under open field condition throughout the growing season of the plant in producing the longest spike stem length in both seasons, scoring 34.70, 35.40 and $35.83 \mathrm{~cm}$ in the first season and 36.83, 37.37 and $37.90 \mathrm{~cm}$ in the second one, respectively. In contrast, the least scores were obtained due to bulbs planted on November $1^{\text {st }}$ under open field condition throughout the growth season of the plants $(29.00$ and $31.00 \mathrm{~cm}$ in the first and second seasons, respectively).

Data scored in Table (6) revealed negligible differences on spike stem diameter due to growing plants under either open field condition throughout the growing season of the plant or under shading followed by open field conditions in the two seasons $(0.66$ and $0.73 \mathrm{~cm}$ in the first season and 0.72 and $0.75 \mathrm{~cm}$ in the second one, respectively). On the other side, spike stem diameter progressively decreased by delaying planting date in the two seasons. The interactions, indicated the superiority of growing plants under shading followed by open field condition with planting on September $15^{\text {th }}$ in raising spike stem diameter in the two seasons (0.89 and 0.84 $\mathrm{cm}$, respectively). The least scores, on the other side, were a result of growing plants under open field condition throughout the growing season of the plant with planting on November $1^{\text {st }}$ in the two seasons ( 0.60 and $0.61 \mathrm{~cm}$, respectively).

Referring to the effect on fresh weight of cut spike (Table 7), slight effects on such trait was observed due to using the different planting conditions. However, it could be mentioned that growing plants under shading followed by open field conditions raised to some extent fresh weight of cut spike than that obtained from plants grown at open field condition throughout the growing seasons registering 33.21 and 35.32 g against 32.70 and $33.89 \mathrm{~g}$ in the first and second seasons, respectively. Planting dates, indicated that planting the bulbs at the earliest date of September $15^{\text {th }}$ was the best for elevating 


\section{Z.H.R Abdel-Said}

Table 6. Effect of planting conditions and planting dates on spike stem diameter $(\mathrm{cm})$ of Iris tingitana cv. Wedgewood during 2016/2017 and 2017/2018 seasons.

\begin{tabular}{|c|c|c|c|c|c|c|c|c|c|c|}
\hline \multirow{2}{*}{ Dates (B) } & $\begin{array}{l}\text { Open/ } \\
\text { Open }\end{array}$ & $\begin{array}{c}\text { Shade/ } \\
\text { Open }\end{array}$ & $\begin{array}{l}\text { Open/ } \\
\text { Shade }\end{array}$ & $\begin{array}{l}\text { Shade/ } \\
\text { Shade }\end{array}$ & Means & $\begin{array}{l}\text { Open/ } \\
\text { Open }\end{array}$ & $\begin{array}{l}\text { Shade/ } \\
\text { Open }\end{array}$ & $\begin{array}{l}\text { Open/ } \\
\text { Shade }\end{array}$ & $\begin{array}{l}\text { Shade/ } \\
\text { Shade }\end{array}$ & Means \\
\hline & \multicolumn{5}{|c|}{$1^{\text {st }}$ season } & \multicolumn{5}{|c|}{$2^{\text {nd }}$ season } \\
\hline Sep. 15 & 0.65 & 0.89 & - & - & 0.77 & 0.71 & 0.84 & - & - & 0.78 \\
\hline Oct. 1 & 0.63 & 0.79 & - & - & 0.71 & 0.72 & 0.83 & - & - & 0.77 \\
\hline Oct. 15 & 0.77 & 0.62 & - & - & 0.69 & 0.84 & 0.70 & - & - & 0.76 \\
\hline Nov. 1 & 0.60 & 0.61 & - & - & 0.61 & 0.61 & 0.62 & - & - & 0.62 \\
\hline Means & 0.66 & 0.73 & - & - & & 0.72 & 0.75 & - & - & \\
\hline LSD at 0.05 & $\begin{array}{l}A=0.063 \\
B=0.121 \\
A \times B=0.1\end{array}$ & & & & & $\begin{array}{l}\mathrm{A}=0.075 \\
\mathrm{~B}=0.143 \\
\mathrm{~A} \times \mathrm{B}=0 .\end{array}$ & & & & \\
\hline
\end{tabular}

Table 7. Effect of planting conditions and planting dates on fresh weight of cut spike (g) of Iris tingitana cv. Wedgewood during 2016/2017 and 2017/2018 seasons.

\begin{tabular}{|c|c|c|c|c|c|c|c|c|c|c|}
\hline \multirow{2}{*}{ Dates (B) } & $\begin{array}{l}\text { Open/ } \\
\text { Open }\end{array}$ & $\begin{array}{l}\text { Shade/ } \\
\text { Open }\end{array}$ & $\begin{array}{l}\text { Open/ } \\
\text { Shade }\end{array}$ & $\begin{array}{l}\text { Shade/ } \\
\text { Shade }\end{array}$ & Means & $\begin{array}{l}\text { Open/ } \\
\text { Open }\end{array}$ & $\begin{array}{l}\text { Shade/ } \\
\text { Open }\end{array}$ & $\begin{array}{l}\text { Open/ } \\
\text { Shade }\end{array}$ & $\begin{array}{l}\text { Shade/ } \\
\text { Shade }\end{array}$ & Means \\
\hline & \multicolumn{5}{|c|}{$1^{\text {st }}$ season } & \multicolumn{5}{|c|}{$2^{\text {nd }}$ season } \\
\hline Sep. 15 & 34.90 & 37.53 & - & - & 51.22 & 33.47 & 39.60 & - & - & 36.53 \\
\hline Oct. 1 & 29.73 & 34.23 & - & - & 31.98 & 31.77 & 36.37 & - & - & 34.06 \\
\hline Oct. 15 & 36.50 & 30.40 & - & - & 33.45 & 38.67 & 32.63 & - & - & 35.60 \\
\hline Nov. 1 & 29.67 & 30.67 & - & - & 30.17 & 31.67 & 32.67 & - & - & 32.17 \\
\hline Means & 32.70 & 33.21 & - & - & & 33.89 & 35.32 & - & - & \\
\hline \multirow{3}{*}{ LSD at 0.05} & \multicolumn{5}{|c|}{$A=1.964$} & \multicolumn{5}{|l|}{$\mathrm{A}=1.843$} \\
\hline & \multirow{2}{*}{\multicolumn{5}{|c|}{$\begin{array}{l}\mathrm{B}=4.781 \\
\mathrm{~A} \times \mathrm{B}=4.970\end{array}$}} & \multicolumn{5}{|l|}{$B=3.518$} \\
\hline & & & & & & \multicolumn{5}{|c|}{$\mathrm{A} \times \mathrm{B}=3.685$} \\
\hline
\end{tabular}

fresh weight of cut spike than that gained from the other planting dates were used in both seasons (51.22 and $36.53 \mathrm{~g}$ in the first and second seasons, respectively). In contrast, the least scores were obtained due to planting the bulbs in the latest date of November $1^{\text {st }}$ registering only 30.17 and $32.17 \mathrm{~g}$ in the first and second seasons, respectively. Concerning the interaction, it is clear from data that planting the bulbs on September $15^{\text {th }}$ with growing plants under shading, followed by open field conditions succeeded to produce the heaviest fresh weight of cut spike in both seasons (37.35 and $39.60 \mathrm{~g}$, respectively). The least scores were gained as a result of growing plants under open field condition throughout the growing season with planting in the latest date of November $1^{\text {st }}$, scoring only 29.67 and
$31.67 \mathrm{~g}$ in the first and second seasons, respectively.

On the other side, bulbs grown at either shading condition allover the growing season or that grown at open field condition followed by shading condition failed to flowering in the two seasons.

\section{Effect on bulb production:}

Data exhibited in Table (8) exert the significant influence of growing plants under shading followed by open field conditions in raising fresh weight of newly formed bulbs than that gained from the other planting condition used in both seasons (12.35 and $11.27 \mathrm{~g}$ in the first and second seasons, respectively). Meanwhile, the least scores were obtained due to growing plants under 
Table 8. Effect of planting conditions and planting dates on bulbs fresh weight (g) of Iris tingitana $\mathrm{cv}$. Wedgewood during $2016 / 2017$ and $2017 / 2018$ seasons.

\begin{tabular}{|c|c|c|c|c|c|c|c|c|c|c|}
\hline \multirow{2}{*}{ Dates (B) } & $\begin{array}{l}\text { Open/ } \\
\text { Open }\end{array}$ & $\begin{array}{c}\text { Shade/ } \\
\text { Open }\end{array}$ & $\begin{array}{l}\text { Open/ } \\
\text { Shade }\end{array}$ & $\begin{array}{l}\text { Shade/ } \\
\text { Shade }\end{array}$ & Means & $\begin{array}{l}\text { Open/ } \\
\text { Open }\end{array}$ & $\begin{array}{c}\text { Shade/ } \\
\text { Open }\end{array}$ & $\begin{array}{l}\text { Open/ } \\
\text { Shade }\end{array}$ & $\begin{array}{l}\text { Shade/ } \\
\text { Shade }\end{array}$ & Means \\
\hline & \multicolumn{5}{|c|}{$1^{\text {st }}$ season } & \multicolumn{5}{|c|}{$2^{\text {nd }}$ season } \\
\hline Sep. 15 & 12.94 & 12.31 & 6.76 & 6.25 & 9.56 & 12.65 & 11.80 & 6.23 & 5.66 & 9.08 \\
\hline Oct. 1 & 9.44 & 11.80 & 7.60 & 7.08 & 8.98 & 8.78 & 10.56 & 7.32 & 6.80 & 8.37 \\
\hline Oct. 15 & 10.77 & 11.25 & 8.37 & 7.50 & 9.47 & 10.25 & 10.22 & 8.09 & 6.98 & 8.89 \\
\hline Nov. 1 & 7.09 & 14.06 & 6.83 & 6.45 & 8.60 & 6.56 & 12.50 & 6.43 & 5.80 & 7.82 \\
\hline Means & 10.06 & 12.35 & 7.39 & 6.82 & & 9.56 & 11.27 & 7.02 & 6.31 & \\
\hline LSD at 0.05 & $\begin{array}{l}A=N . S \\
B=N . S \\
A \times B=N . S\end{array}$ & & & & & $\begin{array}{l}A=N . S \\
B=N . S \\
A \times B=N . S\end{array}$ & & & & \\
\hline
\end{tabular}

shading condition throughout the growing season (6.82 and $6.31 \mathrm{~g}$ in the first and second seasons, respectively). On the other hand, the heaviest fresh weight of bulbs were gained as a result of planting on September $15^{\text {th }}$ in both seasons (9.56 and $9.08 \mathrm{~g}$, respectively) whereas, the least scores was a result of bulbs planted in the latest date of November $1^{\text {st }}$ scoring only 8.60 and $7.82 \mathrm{~g}$ in the first and second seasons, respectively. The interactions, on the other side, revealed the increment of bulb fresh weight with giving the utmost high values for bulbs planted in the earliest date (September $15^{\text {th }}$ ) with growing plants at either open field condition throughout the growing season or growing the bulbs under shading followed by open field condition, scoring 12.94 and 12.31 in the first season and 12.65 and 11.80 $\mathrm{g}$ in the second one, respectively). The opposite was the right as the least scores were obtained as a result of planting on November $1^{\text {st }}$ with growing plants under shading condition throughout the growing season (6.45 and $5.80 \mathrm{~g}$ in the first and second seasons, respectively).

Bulbs circumference insignificantly affected by the different treatments used in both seasons (Table 9). However, it could be mentioned that growing the bulbs under open field condition throughout the growing season or growing them under shading followed by open field condition were the best treatments used in raising bulb circumference in both seasons (8.36 and 8.40 $\mathrm{cm}$ in the first season and 8.17 and $8.20 \mathrm{~cm}$ in the second one, respectively). The least score, on the other side, was obtained resulting from growing plants under shading condition throughout the growing season (6.94 and $6.72 \mathrm{~cm}$ in the first and second seasons, respectively). The highest bulb circumference, on the other hand, resulted from planting on October $15^{\text {th }}$ in both seasons (8.21 and $7.91 \mathrm{~cm}$, respectively), whereas, the least scores were obtained due to planting on November $1^{\text {st }}$, registering only 7.03 and $6.80 \mathrm{~cm}$ in the first and second seasons, respectively. Referring to the interaction, the highest scores were obtained due to planting on September $15^{\text {th }}$ with growing plants under open field condition throughout the growing season (9.02 and $8.86 \mathrm{~cm}$ in the first and second seasons, respectively). The opposite was the right as the least scores were obtained due to planting on November $1^{\text {st }}$ with growing plants under shading condition throughout the growing season (6.39 and $6.18 \mathrm{~cm}$ in the first and second seasons, respectively).

Negligible and insignificant effects were observed on bulbs yield (No. of newly formed bulbs/plot) due to applying the different treatments in both seasons, Table (10). 
Table 9. Effect of planting conditions and planting dates on bulbs circumference (cm) of Iris tingitana cv. Wedgewood during $2016 / 2017$ and 2017/2018 seasons.

\begin{tabular}{|c|c|c|c|c|c|c|c|c|c|c|}
\hline \multirow{2}{*}{ Dates (B) } & $\begin{array}{l}\text { Open/ } \\
\text { Open }\end{array}$ & $\begin{array}{c}\text { Shade/ } \\
\text { Open }\end{array}$ & $\begin{array}{l}\text { Open/ } \\
\text { Shade }\end{array}$ & $\begin{array}{l}\text { Shade/ } \\
\text { Shade }\end{array}$ & Means & $\begin{array}{l}\text { Open/ } \\
\text { Open }\end{array}$ & $\begin{array}{c}\text { Shade/ } \\
\text { Open }\end{array}$ & $\begin{array}{l}\text { Open/ } \\
\text { Shade }\end{array}$ & $\begin{array}{l}\text { Shade/ } \\
\text { Shade }\end{array}$ & Means \\
\hline & \multicolumn{5}{|c|}{$1^{\text {st }}$ season } & \multicolumn{5}{|c|}{$2^{\text {nd }}$ season } \\
\hline Sep. 15 & 9.02 & 8.83 & 7.16 & 6.68 & 7.92 & 8.86 & 8.65 & 6.89 & 6.45 & 7.71 \\
\hline Oct. 1 & 8.32 & 8.28 & 7.35 & 7.47 & 7.85 & 8.18 & 8.09 & 7.05 & 7.25 & 7.64 \\
\hline Oct. 15 & 8.74 & 8.85 & 8.05 & 7.22 & 8.21 & 8.45 & 8.66 & 7.53 & 7.00 & 7.91 \\
\hline Nov. 1 & 7.36 & 7.64 & 6.74 & 6.39 & 7.03 & 7.17 & 7.35 & 6.48 & 6.18 & 6.80 \\
\hline Means & 8.36 & 8.40 & 7.33 & 6.94 & & 8.17 & 8.20 & 6.98 & 6.72 & \\
\hline LSD at 0.05 & $\begin{array}{l}A=N . S \\
B=N . S \\
A \times B=N . S\end{array}$ & & & & & $\begin{array}{l}A=N . S \\
B=N . S \\
A \times B=N . S\end{array}$ & & & & \\
\hline
\end{tabular}

Table 10. Effect of planting conditions and planting dates on bulbs yield of Iris tingitana cv. Wedgewood during 2016/2017 and 2017/2018 seasons.

\begin{tabular}{|c|c|c|c|c|c|c|c|c|c|c|}
\hline \multirow{2}{*}{ Dates (B) } & $\begin{array}{c}\text { Open/ } \\
\text { Open }\end{array}$ & $\begin{array}{c}\text { Shade/ } \\
\text { Open }\end{array}$ & $\begin{array}{l}\text { Open/ } \\
\text { Shade }\end{array}$ & $\begin{array}{l}\text { Shade/ } \\
\text { Shade }\end{array}$ & Means & $\begin{array}{l}\text { Open/ } \\
\text { Open }\end{array}$ & $\begin{array}{c}\text { Shade/ } \\
\text { Open }\end{array}$ & $\begin{array}{l}\text { Open/ } \\
\text { Shade }\end{array}$ & $\begin{array}{l}\text { Shade/ } \\
\text { Shade }\end{array}$ & Means \\
\hline & \multicolumn{5}{|c|}{$1^{\text {st }}$ season } & \multicolumn{5}{|c|}{$2^{\text {nd }}$ season } \\
\hline $\begin{array}{l}\text { Sep. } 15 \\
\end{array}$ & 5.00 & 5.06 & 4.31 & 4.33 & 4.67 & 4.56 & 4.67 & 4.00 & 4.11 & 4.34 \\
\hline Oct. 1 & 4.67 & 4.66 & 4.68 & 4.05 & 4.50 & 4.40 & 4.52 & 4.56 & 3.79 & 4.32 \\
\hline Oct. 15 & 4.33 & 5.32 & 4.34 & 5.09 & 4.75 & 4.21 & 5.09 & 4.25 & 4.87 & 4.61 \\
\hline Nov. 1 & 4.00 & 4.30 & 4.32 & 3.67 & 4.08 & 3.68 & 3.98 & 4.05 & 3.40 & 3.78 \\
\hline Means & 4.50 & 4.83 & 4.42 & 4.25 & & 4.21 & 4.57 & 4.22 & 4.04 & \\
\hline \multirow[t]{3}{*}{ LSD at 0.05} & \multicolumn{5}{|l|}{$A=N . S$} & \multicolumn{5}{|l|}{$A=N . S$} \\
\hline & \multirow{2}{*}{\multicolumn{5}{|c|}{$\begin{array}{l}B=N . S \\
A \times B=N S\end{array}$}} & \multicolumn{5}{|l|}{$B=N . S$} \\
\hline & & & & & & \multicolumn{5}{|c|}{$\mathrm{A} \times \mathrm{B}=\mathrm{N} . \mathrm{S}$} \\
\hline
\end{tabular}

\section{Effect on bulblets production:}

Data outlined in Table (11) exert the beneficial effect of growing plants under shading, followed by open field conditions in raising bulblets fresh weight in both seasons comparing with that gained from the other conditions used (Table 11). Such treatment raised bulblets fresh weight to 2.34 and 1.92 $\mathrm{g}$ in the first and second seasons, respectively. Meanwhile, the opposite was the right for bulbs grown under shading condition throughout the growing season as this treatment declined the scored values to the minimum values in both seasons, registering only 1.07 and $1.04 \mathrm{~g}$ in the first and second seasons, respectively. On the other side, planting the bulbs in the earliest date of October $15^{\text {th }}$ recorded the utmost high values of bulblets fresh weight in the two seasons (2.03 and $1.75 \mathrm{~g}$ in the first and second seasons, respectively). Whereas, the least scores in this regard was a result of delaying planting date to November $1^{\text {st }}$ as this treatment declined fresh weight of bulblet to only 1.39 and $1.21 \mathrm{~g}$ in the first and second seasons, respectively. With regard to the interactions it is clear from data of Table (11) that bulbs planted on October $15^{\text {th }}$ and grown under shading followed by open field condition gave the utmost high values of fresh weight of bulblet in the two seasons, registering 2.65 and $2.18 \mathrm{~g}$ in the first and second seasons, respectively. On the contrary, the least scores in this regard were obtained from bulbs planted on October $1^{\text {st }}$ and grown under shading condition throughout the growing season, scoring only 
Table 11. Effect of planting conditions and planting dates on bulblets fresh weight (g) of Iris tingitana cv. Wedgewood during $2016 / 2017$ and 2017/2018 seasons.

\begin{tabular}{|c|c|c|c|c|c|c|c|c|c|c|}
\hline \multirow{2}{*}{ Dates (B) } & $\begin{array}{c}\text { Open/ } \\
\text { Open }\end{array}$ & $\begin{array}{c}\text { Shade/ } \\
\text { Open }\end{array}$ & $\begin{array}{l}\text { Open/ } \\
\text { Shade }\end{array}$ & $\begin{array}{l}\text { Shade/ } \\
\text { Shade }\end{array}$ & Means & $\begin{array}{l}\text { Open/ } \\
\text { Open }\end{array}$ & $\begin{array}{l}\text { Shade/ } \\
\text { Open }\end{array}$ & $\begin{array}{l}\text { Open/ } \\
\text { Shade }\end{array}$ & $\begin{array}{l}\text { Shade/ } \\
\text { Shade }\end{array}$ & Means \\
\hline & \multicolumn{5}{|c|}{$1^{\text {st }}$ season } & \multicolumn{5}{|c|}{$2^{\text {nd }}$ season } \\
\hline Sep. 15 & 2.61 & 2.55 & 1.26 & 1.05 & 1.87 & 2.23 & 2.19 & 1.08 & 1.02 & 1.63 \\
\hline Oct. 1 & 1.84 & 2.34 & 1.70 & 1.02 & 1.73 & 1.23 & 1.89 & 1.34 & 1.00 & 1.37 \\
\hline Oct. 15 & 2.33 & 2.65 & 2.06 & 1.07 & 2.03 & 2.09 & 2.18 & 1.68 & 1.05 & 1.75 \\
\hline Nov. 1 & 1.53 & 1.81 & 1.08 & 1.14 & 1.39 & 1.25 & 1.42 & 1.07 & 1.09 & 1.21 \\
\hline Means & 2.08 & 2.34 & 1.53 & 1.07 & & 1.70 & 1.92 & 1.29 & 1.04 & \\
\hline \multirow[t]{3}{*}{ LSD at 0.05} & \multicolumn{5}{|c|}{$A=0.273$} & \multicolumn{5}{|c|}{$A=0.205$} \\
\hline & \multirow{2}{*}{\multicolumn{5}{|c|}{$\begin{array}{l}B=0.273 \\
A \times B=0.546\end{array}$}} & \multicolumn{5}{|c|}{$\mathrm{B}=0.205$} \\
\hline & & & & \multicolumn{5}{|c|}{$\mathrm{A} \times \mathrm{B}=0.427$} \\
\hline
\end{tabular}

1.02 and $1.00 \mathrm{~g}$ in the first and second seasons, respectively.

Bulblets yield (No. of bulblets/plot) significantly affected by the different planting condition and dates used in both seasons (Table 12). In this concern, the utmost highest values were obtained due to growing the bulbs under open field condition throughout the growing season and those which grown under shading and followed by open field condition. They registered 18.67 and 19.33 in the first season and 17.64 and 18.32 in the second one, respectively. Meanwhile, the lowest records were gained as a result of growing plants under shading conditions throughout the growing season, scoring only 11.00 and 10.22 in the first and second seasons, respectively. Referring the effect of planting dates, bulbs planted on October $15^{\text {th }}$ gave the best result in producing the highest bulblets yield in both seasons (18.58 and 17.10 in the first and second seasons, respectively). Meanwhile, the opposite was the right as the lowest record of bulblets yield was a result of planting on November $1^{\text {st }}$, scoring only 12.67 and 11.92 in the first and second seasons, respectively. With respect to the beneficial effect of the early planting date on bulbs, corms, bulblets and cormlets quality. Many authors agreed such result on other bulbs as mentioned by Arafa et al. (2000) on Polianthes tuberosa, studied the effect of different planting dates (April $17^{\text {th }}$, May $2^{\text {nd }}$, May $17^{\text {th }}$ and June $1^{\text {st }}$ ) and found that planting the bulbs early increased number of bulblets/plot (bulblets yield). Moreover, Eliwa et al. (2010b) on Freesia refracta cv. Aurora concluded that planting the corms in the earliest date (September $16^{\text {th }}$ ) increased cormels yield. Concerning the interactions. The highest records of the same trait were obtained as a result of bulbs planted on October $15^{\text {th }}$ with growing plants at either open field condition throughout the growing season or at shading followed by open field condition, registering 22.33 and 22.67 in the first season and 20.88 and 21.09 in the second one, respectively. On the contrary, the least scores were obtained due to planting the bulbs on October $1^{\text {st }}$ with growing plants under shading condition throughout the growing season, scoring only 9.67 and 9.33 in the first and second seasons, respectively.

\section{Effect on chemical constituents:}

\section{Pigments content:}

Data outlined in Tables (13, 14 and 15) exert the beneficial effect of planting the bulbs under open field followed by shading conditions in raising pigment contents in leaves in both seasons. Meanwhile, In contrast, bulbs planted under open field condition throughout the growing season recorded the lowest records in the two seasons. Referring to the effects of planting dates, the utmost high values of pigments content in leaves was noticed as a result of 
Table 12. Effect of planting conditions and planting dates on bulblets yield of Iris tingitana cv. Wedgewood during $2016 / 2017$ and $2017 / 2018$ seasons.

\begin{tabular}{|c|c|c|c|c|c|c|c|c|c|c|}
\hline \multirow{2}{*}{ Dates (B) } & $\begin{array}{l}\text { Open/ } \\
\text { Open }\end{array}$ & $\begin{array}{c}\text { Shade/ } \\
\text { Open }\end{array}$ & $\begin{array}{l}\text { Open/ } \\
\text { Shade }\end{array}$ & $\begin{array}{l}\text { Shade/ } \\
\text { Shade }\end{array}$ & Means & $\begin{array}{l}\text { Open/ } \\
\text { Open }\end{array}$ & $\begin{array}{c}\text { Shade/ } \\
\text { Open }\end{array}$ & $\begin{array}{l}\text { Open/ } \\
\text { Shade }\end{array}$ & $\begin{array}{l}\text { Shade/ } \\
\text { Shade }\end{array}$ & Means \\
\hline & \multicolumn{5}{|c|}{$1^{\text {st }}$ season } & \multicolumn{5}{|c|}{$2^{\text {nd }}$ season } \\
\hline Sep. 15 & 20.33 & 20.00 & 11.67 & 10.00 & 15.50 & 19.85 & 19.46 & 10.88 & 9.78 & 15.00 \\
\hline Oct. 1 & 17.33 & 19.67 & 12.00 & 9.67 & 14.67 & 16.50 & 18.54 & 11.65 & 9.33 & 14.05 \\
\hline Oct. 15 & 22.33 & 22.67 & 15.67 & 13.67 & 18.58 & 20.88 & 21.09 & 14.86 & 11.55 & 17.10 \\
\hline Nov. 1 & 14.67 & 15.00 & 10.33 & 10.67 & 12.67 & 13.32 & 14.23 & 9.89 & 10.23 & 11.92 \\
\hline Means & 18.67 & 19.33 & 12.42 & 11.00 & & 17.64 & 18.32 & 11.82 & 10.22 & \\
\hline LSD at 0.05 & $\begin{array}{l}\mathrm{A}=2.706 \\
\mathrm{~B}=2.706 \\
\mathrm{~A} \times \mathrm{B}=4 .\end{array}$ & & & & & $\begin{array}{l}A=1.562 \\
B=1.562 \\
A \times B=3 .\end{array}$ & & & & \\
\hline
\end{tabular}

Table 13. Effect of planting conditions and planting dates on chlorophyll a (mg/g f.w.) of Iris tingitana cv. Wedgewood during 2016/2017 and 2017/2018 seasons.

\begin{tabular}{|c|c|c|c|c|c|c|c|c|c|c|}
\hline \multirow{2}{*}{ Dates (B) } & $\begin{array}{l}\text { Open/ } \\
\text { Open }\end{array}$ & $\begin{array}{c}\text { Shade/ } \\
\text { Open }\end{array}$ & $\begin{array}{l}\text { Open/ } \\
\text { Shade }\end{array}$ & $\begin{array}{l}\text { Shade/ } \\
\text { Shade }\end{array}$ & Means & $\begin{array}{l}\text { Open/ } \\
\text { Open }\end{array}$ & $\begin{array}{c}\text { Shade/ } \\
\text { Open }\end{array}$ & $\begin{array}{l}\text { Open/ } \\
\text { Shade }\end{array}$ & $\begin{array}{l}\text { Shade/ } \\
\text { Shade }\end{array}$ & Means \\
\hline & \multicolumn{5}{|c|}{$1^{\text {st }}$ season } & \multicolumn{5}{|c|}{$2^{\text {nd }}$ season } \\
\hline$\overline{\text { Sep. } 15}$ & 0.032 & 0.640 & 0.682 & 0.650 & 0.501 & 0.029 & 0.598 & 0.534 & 0.471 & 0.473 \\
\hline Oct. 1 & 0.236 & 0.246 & 0.332 & 0.231 & 0.261 & 0.202 & 0.228 & 0.286 & 0.223 & 0.235 \\
\hline Oct. 15 & 0.088 & 0.057 & 0.292 & 0.168 & 0.151 & 0.079 & 0.049 & 0.282 & 0.151 & 0.140 \\
\hline Nov. 1 & 0.140 & 0.250 & 0.352 & 0.221 & 0.241 & 0.136 & 0.199 & 0.243 & 0.188 & 0.192 \\
\hline Means & 0.124 & 0.298 & 0.460 & 0.318 & & 0.112 & 0.268 & 0.336 & 0.258 & \\
\hline
\end{tabular}

Table 14. Effect of planting conditions and planting dates on chlorophyll b (mg/g f.w.) of Iris tingitana cv. Wedgewood during 2016/2017 and 2017/2018 seasons.

\begin{tabular}{|c|c|c|c|c|c|c|c|c|c|c|}
\hline \multirow{2}{*}{ Dates (B) } & $\begin{array}{l}\text { Open/ } \\
\text { Open }\end{array}$ & $\begin{array}{c}\text { Shade/ } \\
\text { Open }\end{array}$ & $\begin{array}{l}\text { Open/ } \\
\text { Shade }\end{array}$ & $\begin{array}{l}\text { Shade/ } \\
\text { Shade }\end{array}$ & Means & $\begin{array}{c}\text { Open/ } \\
\text { Open }\end{array}$ & $\begin{array}{c}\text { Shade/ } \\
\text { Open }\end{array}$ & $\begin{array}{l}\text { Open/ } \\
\text { Shade }\end{array}$ & $\begin{array}{l}\text { Shade/ } \\
\text { Shade }\end{array}$ & Means \\
\hline & \multicolumn{5}{|c|}{$1^{\text {st }}$ season } & \multicolumn{5}{|c|}{$2^{\text {nd }}$ season } \\
\hline Sep. 15 & 0.236 & 0.246 & 0.332 & 0.231 & 0.261 & 0.140 & 0.250 & 0.352 & 0.221 & 0.241 \\
\hline Oct. 1 & 0.025 & 0.121 & 0.160 & 0.052 & 0.146 & 0.041 & 0.105 & 0.278 & 0.066 & 0.123 \\
\hline Oct. 15 & 0.096 & 0.081 & 0.121 & 0.081 & 0.097 & 0.076 & 0.030 & 0.142 & 0.081 & 0.082 \\
\hline Nov. 1 & 0.083 & 0.098 & 0.256 & 0.052 & 0.152 & 0.140 & 0.151 & 0.141 & 0.121 & 0.138 \\
\hline Means & 0.097 & 0.136 & 0.217 & 0.104 & & 0.088 & 0.119 & 0.2287 & 0.112 & \\
\hline
\end{tabular}

Table 15. Effect of planting conditions and planting dates on carotenoids (mg/g f.w.) of Iris tingitana cv. Wedgewood during 2016/2017 and 2017/2018 seasons.

\begin{tabular}{|c|c|c|c|c|c|c|c|c|c|c|}
\hline \multirow{2}{*}{ Dates (B) } & $\begin{array}{l}\text { Open/ } \\
\text { Open }\end{array}$ & $\begin{array}{c}\text { Shade/ } \\
\text { Open }\end{array}$ & $\begin{array}{l}\text { Open/ } \\
\text { Shade }\end{array}$ & $\begin{array}{l}\text { Shade/ } \\
\text { Shade }\end{array}$ & Means & $\begin{array}{l}\text { Open/ } \\
\text { Open }\end{array}$ & $\begin{array}{c}\text { Shade/ } \\
\text { Open }\end{array}$ & $\begin{array}{l}\text { Open/ } \\
\text { Shade }\end{array}$ & $\begin{array}{l}\text { Shade/ } \\
\text { Shade }\end{array}$ & Means \\
\hline & \multicolumn{5}{|c|}{$1^{\text {st }}$ season } & \multicolumn{5}{|c|}{$2^{\text {nd }}$ season } \\
\hline Sep. 15 & 0.028 & 0.148 & 0.312 & 0.169 & 0.164 & 0.024 & 0.130 & 0.285 & 0.152 & 0.148 \\
\hline Oct. 1 & 0.041 & 0.105 & 0.278 & 0.066 & 0.123 & 0.033 & 0.098 & 0.256 & 0.052 & 0.109 \\
\hline Oct. 15 & 0.076 & 0.030 & 0.142 & 0.081 & 0.082 & 0.065 & 0.028 & 0.135 & 0.076 & 0.076 \\
\hline Nov. 1 & 0.064 & 0.126 & 0.241 & 0.135 & 0.142 & 0.058 & 0.122 & 0.235 & 0.129 & 0.136 \\
\hline Means & 0.052 & 0.102 & 0.243 & 0.113 & & 0.045 & 0.095 & 0.228 & 0.102 & \\
\hline
\end{tabular}


planting bulbs on September $15^{\text {th }}$. Whereas, the least scores were gained due to planting the bulbs on October $15^{\text {th }}$, in the two seasons. In the matter of interaction, data registered in Tables (13, 14 and 15) indicated the prevalence of growing bulbs under open field, followed by shading conditions with planting the bulbs on September $15^{\text {th }}$ in elevating pigments contents in leaves in both seasons.

\section{Total carbohydrates content in new bulbs (\%):}

Total carbohydrates content in the newly formed bulbs as influenced by the different planting conditions gave means closely near together in the two seasons (Table 16). On the other side, the same constituent was also affected by the different planting dates used in both seasons, where the highest records were gained as a result of planting the bulbs in the earliest date of September $15^{\text {th }}$ in both seasons. Meanwhile, they progressively decreased as a result of delaying planting date. Such result is in accordance with the finding of Eliwa et al. (2010 a) on Freesia refracta $\mathrm{cv}$. Aurora mentioning that planting the corms in the earliest date (September $15^{\text {th }}$ ) increased total carbohydrates in the produced corms. The interaction indicated that bulbs planted on October $1^{\text {st }}$ and grown under open field condition throughout the growing season recorded the highest values of total carbohydrate content in new bulbs (50.230 and 43.035\%. in the first and second seasons, respectively). Whereas, the least scores were a result of bulbs planted in November $1^{\text {st }}$ and grown at either open field or shading condition throughout the growing season, recording 42.805 and $41.540 \%$ in the first season, and 35.981 and $35.325 \%$ in the second one, respectively.

\section{Mineral content in new bulbs:}

\section{Nitrogen \%:}

Clear increment of nitrogen \% in newly formed bulbs was observed in both seasons due to growing plants under open field condition throughout the growing season. Meanwhile, the other condition gave means closely near together in the two seasons. Negligible differences on nitrogen \% were observed due to the effect of the different planting dates were used in both seasons. The interactions, revealed the superiority of planting the bulbs in the latest date of November $1^{\text {st }}$, under shading condition throughout the growing season in raising nitrogen \% in new bulbs in the two seasons.

\section{Phosphorus \%:}

Bulbs planted under open field followed by shading condition as well as those which were grown under shading condition throughout the growing season gave the highest records of phosphorus \% in new bulb in both seasons (Table 18). Meanwhile planting the bulbs on October $1^{\text {st }}$ was the best date for elevating phosphorus \% in bulbs in the two seasons. The interaction on the other hand revealed the superiority of growing the bulbs under open field followed by shading condition with planting the bulbs on October $1^{\text {st }}$ in raising phosphorus \% in new bulbs in the two seasons.

\section{Potassium \%:}

Results of Table (19) reveal the prevalence of growing bulbs under either open field condition throughout the growing season or those which grown under shading followed by open field condition in the first season as well as those grown under open field condition throughout the growing season in the second one in raising potassium accumulation in new bulbs. In this regard El-Hanafy et al. (2005) on Freesia refracta $\mathrm{cv}$. Aurora mentioned that growing plants under shading condition increased the accumulation rate of potassium in new corms. Planting the bulbs on the other hand, in the earliest date of September $15^{\text {th }}$ was the best planting date for producing the highest potassium content in bulbs in the two seasons. The interactions cleared the beneficial effect of growing bulbs under 


\section{Z.H.R Abdel-Said}

Table 16. Effect of planting conditions and planting dates on carbohydrates \% of Iris tingitana cv. Wedgewood during $2016 / 2017$ and $2017 / 2018$ seasons.

\begin{tabular}{|c|c|c|c|c|c|c|c|c|c|c|}
\hline \multirow{2}{*}{ Dates (B) } & $\begin{array}{c}\text { Open/ } \\
\text { Open }\end{array}$ & $\begin{array}{c}\text { Shade/ } \\
\text { Open }\end{array}$ & $\begin{array}{l}\text { Open/ } \\
\text { Shade }\end{array}$ & $\begin{array}{l}\text { Shade/ } \\
\text { Shade }\end{array}$ & Means & $\begin{array}{l}\text { Open/ } \\
\text { Open }\end{array}$ & $\begin{array}{c}\text { Shade/ } \\
\text { Open }\end{array}$ & $\begin{array}{l}\text { Open/ } \\
\text { Shade }\end{array}$ & $\begin{array}{l}\text { Shade/ } \\
\text { Shade }\end{array}$ & Means \\
\hline & \multicolumn{5}{|c|}{$1^{\text {st }}$ season } & \multicolumn{5}{|c|}{$2^{\text {nd }}$ season } \\
\hline Sep. 15 & 47.967 & 45.184 & 46.662 & 49.390 & 47.301 & 39.780 & 37.522 & 38.211 & 41.320 & 39.208 \\
\hline Oct. 1 & 50.230 & 46.196 & 45.852 & 44.256 & 46.634 & 43.035 & 37.908 & 37.721 & 36.070 & 38.684 \\
\hline Oct. 15 & 46.405 & 47.825 & 44.261 & 45.315 & 45.951 & 38.090 & 39.521 & 36.180 & 36.870 & 37.665 \\
\hline Nov. 1 & 42.805 & 45.463 & 44.939 & 41.540 & 43.687 & 35.981 & 37.672 & 36.251 & 35.325 & 36.307 \\
\hline Means & 46.851 & 46.167 & 45.428 & 45.125 & & 39.221 & 38.156 & 37.091 & 37.396 & \\
\hline
\end{tabular}

Table 17. Effect of planting conditions and planting dates on nitrogen \% of Iris tingitana cv. Wedgewood during 2016/2017 and 2017/2018 seasons.

\begin{tabular}{|c|c|c|c|c|c|c|c|c|c|c|}
\hline \multirow{2}{*}{ Dates (B) } & $\begin{array}{c}\text { Open/ } \\
\text { Open }\end{array}$ & $\begin{array}{c}\text { Shade/ } \\
\text { Open }\end{array}$ & $\begin{array}{l}\text { Open/ } \\
\text { Shade }\end{array}$ & $\begin{array}{l}\text { Shade/ } \\
\text { Shade }\end{array}$ & Means & $\begin{array}{l}\text { Open/ } \\
\text { Open }\end{array}$ & $\begin{array}{c}\text { Shade/ } \\
\text { Open }\end{array}$ & $\begin{array}{l}\text { Open/ } \\
\text { Shade }\end{array}$ & $\begin{array}{l}\text { Shade/ } \\
\text { Shade }\end{array}$ & Means \\
\hline & \multicolumn{5}{|c|}{$1^{\text {st }}$ season } & \multicolumn{5}{|c|}{$2^{\text {nd }}$ season } \\
\hline Sep. 15 & 1.508 & 1.076 & 1.086 & 1.295 & 1.241 & 1.342 & 0.835 & 0.890 & 0.950 & 1.004 \\
\hline Oct. 1 & 1.212 & 1.089 & 1.372 & 0.847 & 1.130 & 0.934 & 0.811 & 0.987 & 0.705 & 0.859 \\
\hline Oct. 15 & 1.288 & 1.098 & 0.992 & 1.079 & 1.114 & 0.939 & 0.901 & 0.754 & 0.803 & 0.849 \\
\hline Nov. 1 & 1.217 & 1.059 & 1.101 & 1.654 & 1.258 & 0.928 & 0.798 & 0.921 & 1.490 & 1.034 \\
\hline Means & 1.306 & 1.079 & 1.138 & 1.218 & & 1.036 & 0.836 & 0.888 & 0.987 & \\
\hline
\end{tabular}

Table 18. Effect of planting conditions and planting dates on phosphorus \% of Iris tingitana cv. Wedgewood during 2016/2017 and 2017/2018 seasons.

\begin{tabular}{|c|c|c|c|c|c|c|c|c|c|c|}
\hline \multirow{2}{*}{ Dates (B) } & $\begin{array}{l}\text { Open/ } \\
\text { Open }\end{array}$ & $\begin{array}{c}\text { Shade/ } \\
\text { Open }\end{array}$ & $\begin{array}{l}\text { Open/ } \\
\text { Shade }\end{array}$ & $\begin{array}{l}\text { Shade/ } \\
\text { Shade }\end{array}$ & Means & $\begin{array}{l}\text { Open/ } \\
\text { Open }\end{array}$ & $\begin{array}{c}\text { Shade/ } \\
\text { Open }\end{array}$ & $\begin{array}{l}\text { Open/ } \\
\text { Shade }\end{array}$ & $\begin{array}{l}\text { Shade/ } \\
\text { Shade }\end{array}$ & Means \\
\hline & \multicolumn{5}{|c|}{$1^{\text {st }}$ season } & \multicolumn{5}{|c|}{$2^{\text {nd }}$ season } \\
\hline Sep. 15 & 0.407 & 0.372 & 0.460 & 0.407 & 0.412 & 0.350 & 0.302 & 0.387 & 0.361 & 0.356 \\
\hline Oct. 1 & 0.382 & 0.380 & 0.505 & 0.478 & 0.436 & 0.325 & 0.319 & 0.412 & 0.391 & 0.362 \\
\hline Oct. 15 & 0.339 & 0.372 & 0.423 & 0.497 & 0.408 & 0.298 & 0.307 & 0.376 & 0.407 & 0.347 \\
\hline Nov. 1 & 0.385 & 0.357 & 0.323 & 0.378 & 0.361 & 0.342 & 0.305 & 0.270 & 0.321 & 0.335 \\
\hline Means & 0.378 & 0.369 & 0.427 & 0.440 & & 0.329 & 0.308 & 0.361 & 0.370 & \\
\hline
\end{tabular}

Table 19. Effect of planting conditions and planting dates on potassium \% of Iris tingitana cv. Wedgewood during 2016/2017 and 2017/2018 seasons.

\begin{tabular}{|c|c|c|c|c|c|c|c|c|c|c|}
\hline \multirow{2}{*}{ Dates (B) } & $\begin{array}{c}\text { Open/ } \\
\text { Open }\end{array}$ & $\begin{array}{c}\text { Shade/ } \\
\text { Open }\end{array}$ & $\begin{array}{l}\text { Open/ } \\
\text { Shade }\end{array}$ & $\begin{array}{l}\text { Shade/ } \\
\text { Shade }\end{array}$ & Means & $\begin{array}{l}\text { Open/ } \\
\text { Open }\end{array}$ & $\begin{array}{c}\text { Shade/ } \\
\text { Open }\end{array}$ & $\begin{array}{l}\text { Open/ } \\
\text { Shade }\end{array}$ & $\begin{array}{l}\text { Shade/ } \\
\text { Shade }\end{array}$ & Means \\
\hline & \multicolumn{5}{|c|}{$1^{\text {st }}$ season } & \multicolumn{5}{|c|}{$2^{\text {nd }}$ season } \\
\hline $\begin{array}{l}\text { Sep. } 15 \\
\end{array}$ & 1.819 & 1.499 & 1.750 & 1.683 & 1.688 & 1.650 & 1.280 & 1.509 & 1.451 & 1.473 \\
\hline Oct. 1 & 1.759 & 1.405 & 1.663 & 1.431 & 1.565 & 1.518 & 1.240 & 1.386 & 1.263 & 1.352 \\
\hline Oct. 15 & 1.545 & 1.998 & 1.374 & 1.581 & 1.625 & 1.370 & 1.708 & 1.152 & 1.390 & 1.404 \\
\hline Nov. 1 & 1.544 & 1.760 & 1.366 & 1.891 & 1.640 & 1.365 & 1.550 & 1.135 & 1.690 & 1.435 \\
\hline Means & 1.667 & 1.670 & 1.538 & 1.647 & & 1.468 & 1.445 & 1.296 & 1.449 & \\
\hline
\end{tabular}


shading condition throughout the growing season with planting the bulbs on November $1^{\text {st }}$, giving the utmost high values in new formed bulbs.

\section{REFERENCES}

Al-Ashry, A.I.; Nabih, A. and Ibrahim, GA. (1998). Effect of planting condition and growing media on growth, flowering and chemical constituents of Amaryllis (Hippeastrum vittatum, Herb). Egypt. J. Appl. Sci., 13(4): 208 - 235.

Arafa, N.M.; Abou Dahab, T.A.M. and Nabih, A. (2000). Effect of bulb size and planting date on growth, flowering and bulb productivity of Polianthes tuberosa, L. Egypt. J. Appl. Sci., 17(3): 256 - 274.

Badawy, O.E.F. (1998). Physiological and Anatomical Studies on Tuberosa Bulbs (Polianthes tuberosa, L.). Ph.D. Thesis, Fac. Agric., Cairo Univ., Egypt.

Badawy, O.E.F.; Arafa, N.M. and Nabih, A. (2002). Effect of storage and light intensity on growth, flowering, bulb productivity, chemical constituents and anatomical behavior of stem apex development of Iris cv. Purple Sensation. Egypt. J. Appl. Sci., 17(3): 275 - 304.

Bailey, L.H. (1963). The Standard Cyclopedia of Horticulture vol. 2. The Macmillan Company, New York, pp: 3639.

Blake, GA. (1965). Methods of Soil Analysis, part I and II. Amer. Soc. Agron. Pupl. Madison, Wisconsin, USA.

Dewis, J. and Freitas, F. (1970). Physicological Methods of Soil and Water Analysis. Food and Agric. Organization of the United Nations of Soils Bulletin, No. 10: 275.

Dubois, M.; Gilles, K.A.; Hamilton, J.K.; Rebers, P.T.; and Smith, F. (1956). Colorimetric method for determination of sugars and related substances. Analytical chemistry, 28(3):350-356.
El-Fawakhry, F.M.A. (2001). Studies on Some Factors Affecting Growth, Flowering and Bulbs Productivity of Polianthes tuberosa, L. plant. Ph.D. Thesis, Fac. Agric., Kafr El-Sheikh, Tanta Univ. Egypt.

El-Hanafy, S.H.; Nabih, A. and Badawy, O.E.F. (2005). Effect of shading and chemical fertilization on growth, flowering and corm productivity of Freesia refracta cv. Aurora. Proc. $3^{\text {rd }}$ Conference on Recent Technology in Agri., Cairo, Univ., p 571 - 593.

Eliwa, Y.L.; Rezkalla, B.B. and Nabih, A. (2010a). Effect of some factors on Freesia refracta cv. Aurora plant, 1. Growth and Flowering as influenced by different storage treatments, planting dates and gibberellic acid. Egypt. J. of Appl. Sci., 25 (4B):297 - 336.

Eliwa, Y.L.; Rezkalla, B.B. and Nabih, A. (2010b). Effect of some factors on Freesia refracta cv. Aurora plant, 2. Corms and cormels yield and quality as influenced by different storage treatments, planting dates and gibberellic acid. Egypt. J. of Appl. Sci., 25 (4B):337 -360 .

El-Naggar, A.H. and Swedan, Eman A. (2009). Effect of light intensity and amino acid tryptophan on the growth and flowering of Amaryllis (Hippeastrum vittatum, Herb). J. Agric. and Env. Sci., Alex. Univ., Egypt, 8(1):208-235.

Joh, M.K. (1970). Colorimetric determination of phosphorus in soil and plant materials with ascorbic acid. Soil Sci., 109(4): 214 - 220.

Nada, M.K. (1992). Effect of some growth regulators and shading treatments on Polianthes tuberosa plant, I. Effect of $\mathrm{GA}_{3}$ and shading on growth, flowering and bulb productivity. Egypt. J. Appl. Sci., 7(2):506 - 523.

Page, A.L.; Miller, R.H. and Kenney, D.R. (1982). Methods of Soil Analysis, Part II. 


\title{
Z.H.R Abdel-Said
}

Amer. Soc. Agronomy Inc., Madison, Wisconsin, USA.

SAS (1994). SASISTAT User's Guide; Statistics. Vers. 6.04, $4^{\text {th }}$ ed, SAS Institute Inc. Cary. N.C., USA.

Snedecor, N.W. and Cochran, W.G. (1968). Statistical Methods, $6^{\text {th }}$ ed. The Iowa State Univ. Press., Ames Iowa, USA.
Sorrentino, C.; Cerio, L. and Alvino, A. (1997). Effect of shading and air temperature on leaf photosynthesis, florescence and growth in leaf lily plant. Scientia Hort., 69(314):259-273.

Wettstein, Van D. (1957). Chlorophyll-leta and der sulmikrospsche formwe cheel der plastiden Expth. Cell, Res., 12:427-439.

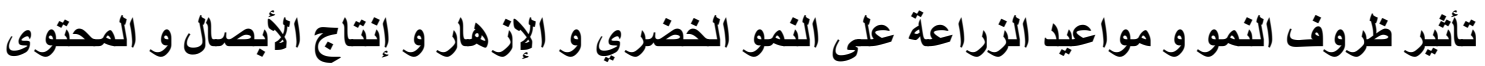 Iris tingitana cv. Wedgewood الكيماوي لنباج}

\author{
زكي حلمي رياض عبد السيد \\ قسم بحوث الزينة وتتسيق الحدائق، معهد بحوثي البساتين، مركز البحوث الزر اعية، الجيزة، مصر.
}

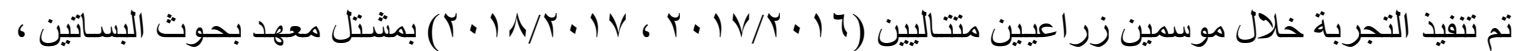

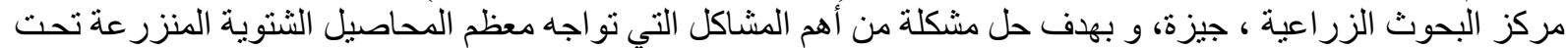

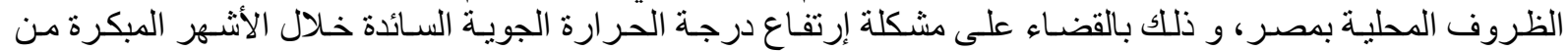

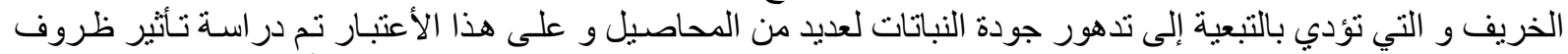

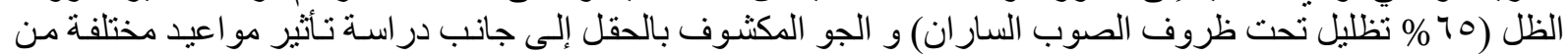

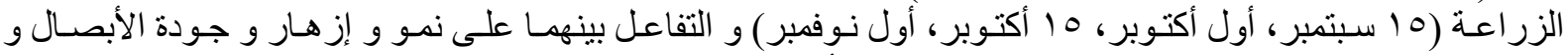

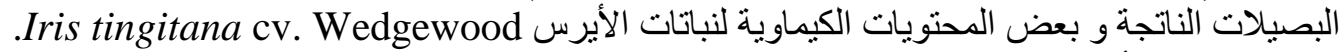
و يمكن تلخيص أهم النتائج لهذه الدر اسة فيما يلئي:

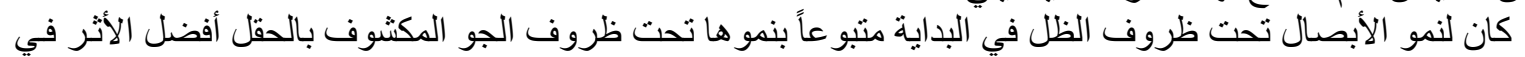

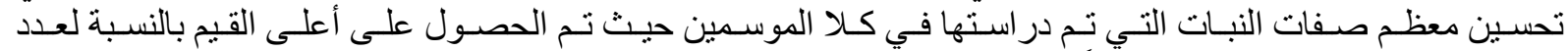

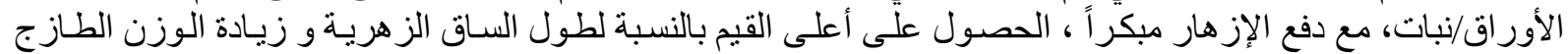

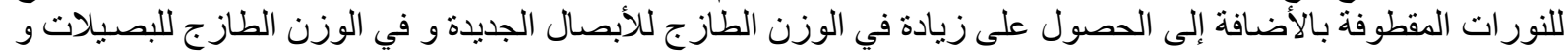

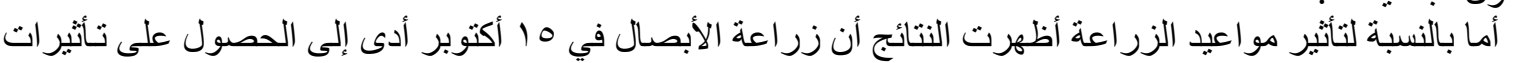

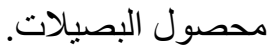

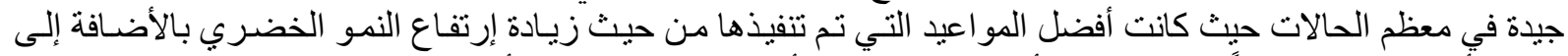

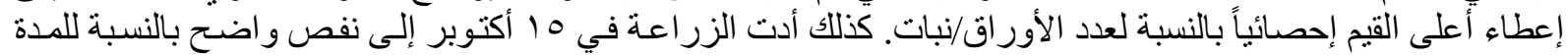

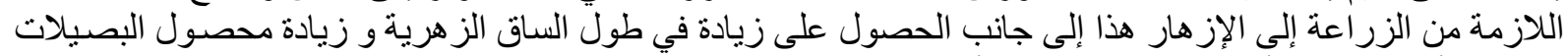

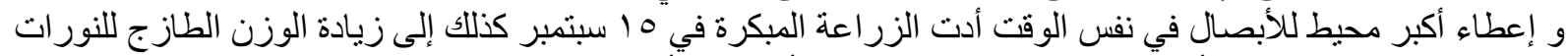

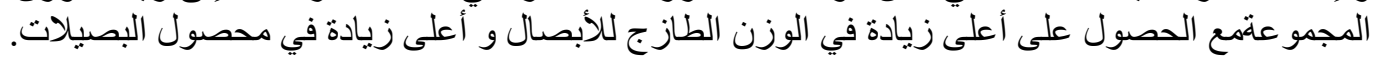

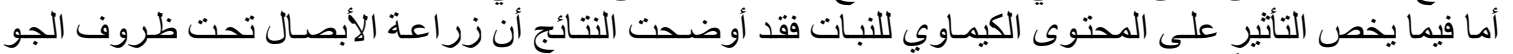

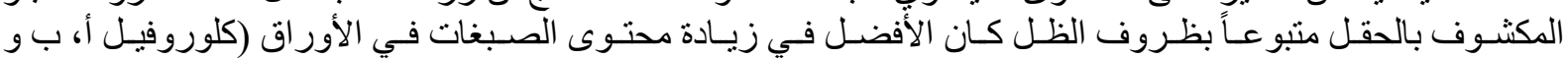

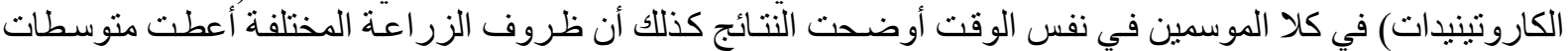

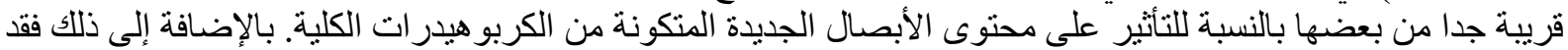

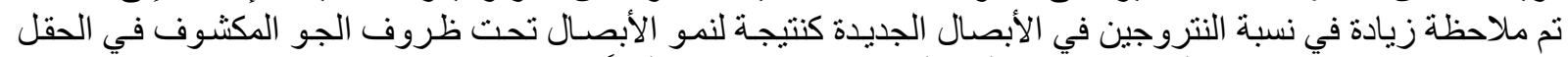

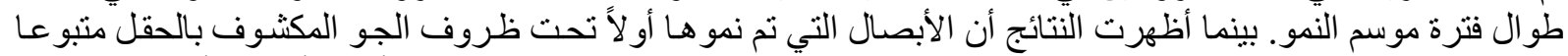

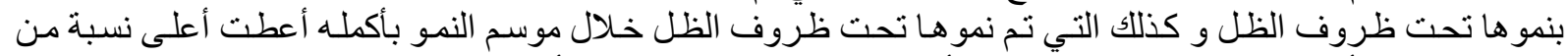

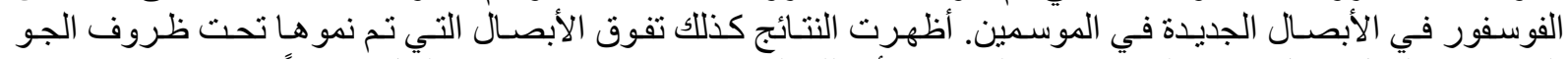

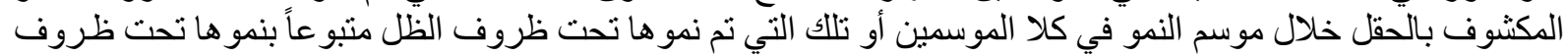

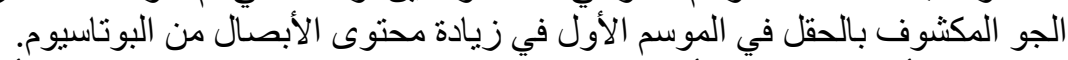

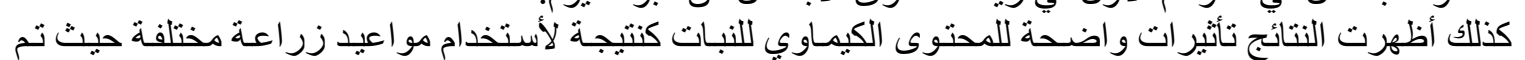

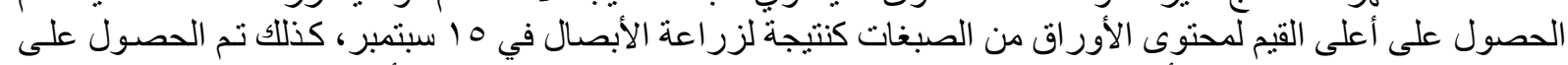

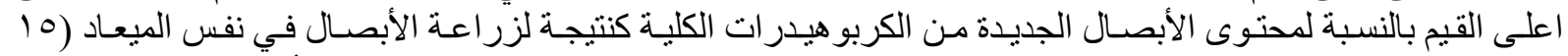

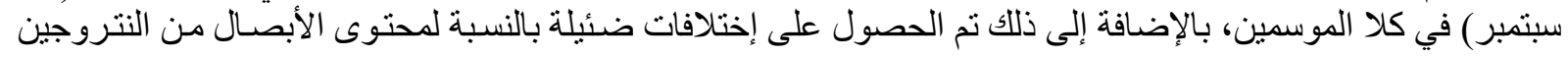




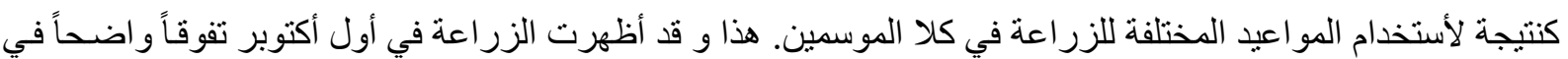

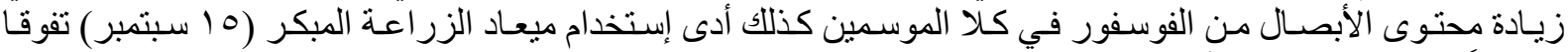
و اضحاً في زيادة محتوى الأبصال من البوتناسيوم في كلا الموسمين.

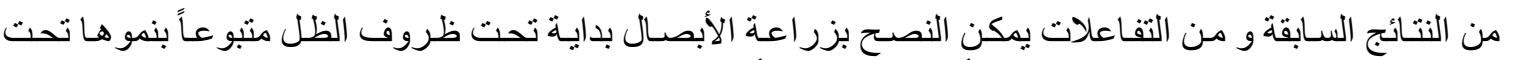

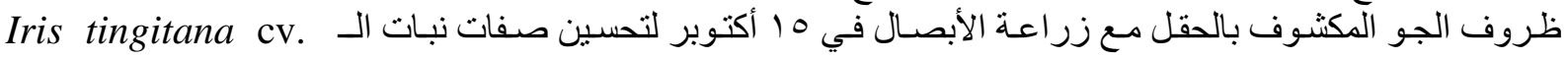
.Wedgewood 